Reprod. Nutr. Dévelop., 1981, 21 (3), 479-496.'

\title{
Early sequential development in avian gonads. An ultrastructural study using selective glycogen labeling
} in the germ cells

\author{
par N. FARGEIX, Eliane DIDIER, P. DIDIER * \\ Laboratoire de Biologie Animale, \\ * Laboratoire de Zoologie. \\ Université de Clermont II, BP 45, 63170 Aubière, France.
}

Summary. The early development of chick embryo gonads was studied by light and transmission electron microscopy and by cytochemical detection of glycogen in primordial germ cells (PGC's). The sequential events are presented from day 2 to day 5 (stages 14 to 27), together with the ultrastructural characteristics of the various cell populations.

This study attempts to contribute data on the controversial origin of the avian gonadal medulla. It is shown that the main part of the primitive medulla arises from the association of the proliferating germinal epithelium (GE) and epithelioid cords (formed early from the condensed splanchnopleural mesenchyme) ; later deep cords, probably developed from the intermediate mesoderm mesenchyme, join the medulla. The process of mesenchymal condensation is described (cells aggregated by dense plaques and membrane anchorages, deposits of fibrillar extracellular material around the cords) together with ultrastructural changes in the GE basal lamina, which is progressively pushed back then disorganized.

The study of the morphological relationships between the PGC's and the somatic cells has been facilitated by glycogen labeling in the former. Whereas the PGC's settled in the germinal epithelia do not display any junctional complex with the epithelial cells up to stage 26 , those which are migrating through the dorsal mesentery and in the deep gonadal mesenchyme are associated to fibroblast-like somatic cells by dense plaques. The cytological characteristics of migrating PGC's (polymorphism, pseudopodia and filopodia, paucity of microfilaments, high $\alpha$-glycogen particle content) have been described. In addition, the cell pattern in mesodermal tissues is thought well-suited to PGC invasion owing to a wide extracellular compartment, distributed in the mesenchyme and the early epithelium, and to discontinuities in the basal lamina.

\section{Introduction.}

Since Swift's classical observations (Swift, 1915, 1916), most of the numerous studies devoted to avian gonadal morphogenesis and underlining both the cytological and the numerical characteristics of primordial germ cells (PGC's), have focused on the germ cell line (reviews in Nieuwkoop and Sutasurya, 1979 ; Fargeix ef al., 1980).

In contrast, knowledge of the gonadal somatic cells remains incomplete, being limited to ultrastructural observations of the so-called « germinal epithelium » at late 
stages (Simone-Santoro, 1969 ; Rahil and Narbaitz, 1972 ; Carlon et al., 1974 ; Didier et al., 1978) and to autoradiographic data on glycoprotein biosynthesis in the germinal epithelia of 3-day embryos cultured in vitro (Cuminge and Dubois, 1971 ; Dubois and Cuminge, 1974).

Some of the data on the origin and the formation of the primitive medulla in sexually indifferent avian gonads are controversial. Considered by Kopp and Bertrand (1978) as mainly deriving from the germinal epithelium, the developing gonad has been suggested to arise from both the condensed mesenchyme and the differentiated coelomic epithelium (Stahl and Carlon, 1973 ; Merchant-Larios, 1978). However, the embryological origin of the mesenchymal moiety and its possible filiation with the mesonephric blastema (Witschi, 1951) remained unsolved and needed to be studied at earlier stages. As gonad formation starts as early as stage 14 in chick and quail embryos (Meyer, 1964 ; Didier and Fargeix, 1976), we re-examined the development of the early gonad by light and transmission electron microscopy, studying sequential morphogenetic events and the ultrastructural characteristics of cell populations between days 2 and 5 of incubation, when the PGC's settle into forming gonads and begin to proliferate. The observation of morphological relationships between somatic and germ cells was facilitated by specific labeling of the glycogen in the germ cells.

\section{Material and methods.}

Our investigations were carried out on a series of 30 chick embryos (Hubbard strain) incubated for 2, 3, 4 or 5 days and staged according to Hamburger and Hamilton (1951). The gonadal area in younger embryos (stages 15 to 23), fixed whole, was determined on thick serial cross-sections of 1-2 $\mu \mathrm{m}$. In the older embryos (stages 24 to 27 ), both the genital ridges and the associated mesonephros were quickly isolated prior to fixation.

Every specimen was first immersed in cold $\left(4^{\circ} \mathrm{C}\right) 3 \mathrm{p} .100$ glutaraldehyde in $0.06 \mathrm{M}$ cacodylate buffer $(\mathrm{pH} 7.4)$. rinsed in buffer and then post-fixed in $2 \mathrm{p} .100$

FIGS. 1-10. - Semi-thin cross-sections in developing gonads (to be continued).

FIG. $1(\times 120)$, FIG. $2(\times 500)$, FIG. $4(\times 300)$. - Stage 14-15. The gonadal primordium (short arrow) originates from the splanchnopleura. GE : germinal epithelium with intercellular spaces and one PGC (arrow) ; $S$ : stroma ; $E$ : endoderm ; $N$ : nephrotome.

FIG. $3(\times 300)$. - Stage 18. The asymmetrical gonads (L : left ; $R$ : right) shift and are now situated dorso-laterally to the coelom. PGC's (arrows) are visible in gonads or migrating in the dorsal mesentery.

FIG. 5, FIG. $6(\times 500)$. - Stage 23. Gonads are dorsal to the coelom; the asymmetry between the left (L) and right (R) gonads increases. The GE with enclosed PGC's (arrows) thickens; condensed mesenchyme is seen in the primitive stroma (S).

FIG. 7, FIG. $8(\times 640)$. - Stage 25. The gonadal stroma is organized into dense epithelioid cords (DC) and loose mesenchyme $(\mathrm{M})$. 
osmium tetroxide. After dehydration in graded ethanol and then absolute butanol, the tissues were embedded in Epon 812 (Polysciences). Histological observations were made on thick sections $(1-2 \mu \mathrm{m})$ stained with toluidine blue. For electron microscopy, thin sections were counterstained by uranyl acetate and lead citrate.

Glycogen was detected on other sections mounted on gold grids and then successively treated with 1 p. 100 periodic acid, 0.2 p. 100 thiocarbohydrazide in 20 p. 100 acetic acid (TCH from Eastman) for $24 \mathrm{~h}$ and then silver proteinate (Roques). This reaction, designed by Thiéry (1967), is referred to as the «PA-T-Ag 》 reaction; its specificity was tested by omitting PA oxidation prior to TCH and Ag treatments. PA-T-Ag-treated secfions were observed without any subsequent counterstain. All observations were made with a Siemens Elmiskop $1 \mathrm{~A}$ electron microscope.

\section{Observations.}

1) Stages 15 to 17. - Widely separated from the developing nephrotome situated more dorsally, the gonadal primordia in 2-day embryos appeared first as two longitudinal areas of splanchnopleural mesoderm ventro-lateral to the coelomic cavity (figs. 1, 2, 4). The gonadal mesoderm was arranged in two distinct layers : an epithelial sheet termed the "germinal epithelium » (GE) and a thin stroma of condensed mesenchyme lying dorsal to the endoderm (fig. 11). Blood capillaries with enclosed PGC's branched out in the stroma so that the PGC's only had to migrate a short distance to settle in the GE. Although the number of PGC's increased more rapidly in the left gonad, the characteristics of the somatic cells were similar in both genital ridges.

A. Germinal epithelium. - The pattern of cellular arrangement was typically epithelial ; the polarity of the GE cells was obviously expressed through their dorsoventral orientation, the apical position of the Golgi apparatus, the centriole and the junctional complexes, and by the basal localization of the nucleus. Nevertheless, the presence of a well-developed extracellular compartment made this epithelial arrange-

FIGS. 1-10. - Semi-thin cross-sections in developing gonads (end).

FIG. $9(\times 500)$, FIG. $10(\times 400)$. - Stage 26. Note contrast in size and organization between right (R) and left (L) gonads. The latter displays a thickened proliferating GE; the GE basal lamina, still present at the lateral edges (arrows), is progressively disorganized in the median axis so that most of the dense stromal cords (DC) are connected to the GE.

FIG. $11(\times 4000)$. - TEM micrograph at stage 15. Apical protrusions and wide intercellular spaces are visible on the coelomic side (arrow) of the GE with an enclosed PGC. The GE is connected to the stromal cords $(D C)$ through disruptions in the basal lamina (BL).

FIG. 12 ( $\times 7000)$. - PA-T-Ag-treated section of the GE at stage 15. Note the wide intercellular spaces. The glycogen granules present in the PGC's are lacking in the somatic epithelial cells (SEC).

FIG. $13(\times 50000)$. - Structural organization of $\beta$-glycogen particles clustered in 50-nm $\alpha$-particles in the PGC's. 
ment unusual : there were wide intercellular spaces between neighbouring cells (figs. $2,11,14$ ) and cell cohesiveness depended solely on apical gap junctions and a thin discontinuous basal lamina (fig. 14). Apical cell membranes displayed either long filopodial or shorter branching expansions which gave a highly villous aspect to the coelomic side of the GE (fig. 11) ; both the lateral and the basal cell surfaces also appeared very convoluted and exhibited many intricate cytoplasmic expansions (fig. 14). Despite such a complex structure, the cellular arrangement was always recognizable in the GE basal area. In the epithelial cells, both desmosome-associated clusters of microfilaments and basal microfilaments without preferential orientation were observed. Some PGC's, lying among the epithelial interspaces, were seen in close contact with the epithelial cells at several points (fig. 11). On PA-T-Ag-treated sections, the PGC's displayed numerous $\alpha$-glycogen particles (50 $\mathrm{nm}$ in diameter) composed of clustered $\beta$-particles. In contrast, the somatic cells were nearly devoid of any glycogen (figs. 12, 13). In spite of the great intricacy of their cell membranes, no specialized contact was found between the PGC's and the epithelial somatic cells at this stage.

B. Epithelial basal lamina. - The basal lamina structure was similar to that described by Sanders (1979) in early chick blastoderms; it consisted of a lamina densa exhibiting some electron-dense granules and of a lucent lamina interna displaying thin fibrillar material joining the plasma membrane of the epithelial cells. The basal lamina was discontinuous which suggested that its three-dimensional structure was a loose, irregular lattice (fig. 14). Contacts between the GE and the subjacent stroma could be seen occasionally through the wide meshes of the basal lamina (fig. 11).

C. Mesenchymal stroma. - As early as stage 15, the gonadal stroma was seen as a multilayered sheet of splanchnopleural mesenchyme which was unambiguously distinct from the mesonephric mesenchyme located more dorsally (fig. 1). Lying in a metachromatic extracellular matrix, the gonadal mesenchyme cells displayed long convoluted filopodia. Mosi of these cells, rich in microfilaments and microfubules, aggregated in small groups sometimes including one PGC (figs. 26, 27). The aggregates, lying just beneath the GE, were connected to it through disruptions in the basal lamina (fig. 11). Deposits of fibrillar extra-cellular material were frequently observed between some of these mesenchymal aggregates which obviously corresponded to very early stages in the formation of the epithelioid cords observed by Stahl and Carlon (1973) and Merchant-Larios (1978) in more advanced embryos (fig. 26).

FIG. $14(\times 30000)$. - Detail of the inset in fig. 11 showing cell organization in the basal GE. Note the discontinuous basal lamina (BL) whose lamina densa (arrow) is connected to fibrillar material surrounding the mesenchymal cell processes (MC).

FIG. 15 ( $\times 17$ 500). - Glycogen labeling in the PGC's (arrows) of the GE emphasizes the infricacy of the filopodia emerging from somatic (SEC) and germ cells.

FIG. $16(\times 10500)$. - Apical protrusions and apical junctions visible in the GE pottern at stage 27. The intercellular spaces present at early stages are no longer seen. 
2) Stages 18 to 20. - At this time, we observed a sequential medio-dorsal shift of the mesonephros, aortas and genital ridges, concomitant with digestive endoderm folding, so that the gonads were found medio-laterally to the coelomic angle (fig. 3 ). In addition, the developing gonads became asymmetrical : the right one was shorter and had a small diameter, and its GE remained flat and thin with large intercellular spaces as at earlier stages. The advanced morphogenesis of the left gonad was expressed by the increased thickness of its multilayered GE and the differentiation of its stroma into two distinct areas. The first area, composed of early epithelioid cords arising from aggregating mesenchymal cells, was seen lying just beneath the GE ; during the condensation process, we observed focal cell contacts, similar to the dense plaques described by Ebendal (1977) in other embryonic tissues (fig. 28). The second area, situated more dorsally, was composed of scattered fibroblast-like cells quite similar to those found in the neighbouring mesonephric mesenchyme.

3) Stages 21 to 24. - From stage 21 onwards, the gonadal primordia, jutting out from the dorsal angle of the coelomic cavity, were visible (figs. $5,6,7,8$ ). The asymmetry between the left and the right gonads increased, the latter displaying little difference with the stages described above, whereas the left gonad grew and changed structurally. Following is a description of the left gonad.

A. Germinal epithelium. - The GE proliferated intensely, leading to a thickening of the epithelial sheet and a progressive obliteration of the wide intercellular spaces previously described. The epithelial cells facing the coelom displayed apical protrusions (fig. 16) ; their lateral membranes, in close apposition, were linked by desmosomes. In contrast, narrow interspaces could be seen between the neighbouring epithelial basal cells which displayed an irregular shape and convoluted filopodial expansions. Microfilaments and microtubules were very numerous in the basal hyaloplasm. Some of these cells showed basal pseudopodial protrusions pushing back the basal lamina towards the underlying stroma (fig. 22). These observations suggest an intense, centripetally-orientated proliferation in the left GE.

FIG. $17(\times 190)$. - Semi-thin section of a left gonad at stage 26 . The GE is connected to the primitive dense stromal cords (DC). New cords (arrow) are forming from the loose mesenchyme connecting the gonad and the mesonephros $(M)$.

FIG. $18(\times 4000)$. - Fibroblastic cells in the loose mesenchyme connecting the gonad and the mesonephros.

FIG. $19(\times 25000)$. - Stage 26. Structure of a dense stromal cord (DC) with surrounding fibrillar material (arrow).

FIG. $20(\times 50000)$. - Stage 27. Disorganization of the GE basal lamina ; granular and fibrillar material (arrows) is seen between the GE and the stromal cords (DC).

FIG. 21 ( $\times 40000$ ). - Stage 25. Reduction of the interspace between a PGC and a somatic epithelial cell (SEC). Note typical mitochondria and glycogen (arrow) in the PGC and microfilaments (MF) and microtubules (MT) in the somatic cell. 
The PCG's included in the GE never lined either the coelom or the basal lamina directly ; they always appeared among the epithelial cells as clumps trapped in narrow cavities. Despite the intricacy of their respective filopodial expansions, visualized by glycogen labeling in the PGC's (fig. 15), specialized junctions could be detected only occasionally between the germ and the epithelial cells. The PGC's also displayed the wide pseudopodia already described by Cuminge and Dubois (1971), Fujimoto ef al. (1976) and Ukeshima and Fujimoto (1978). A striking feature was their paucity of microfilamentous material since only thin microfibrils, clusiered beneath the plasma membrane of the pseudopodia, were seen.

B. Dense mesenchymal stroma. - Mesenchymal cells with a conspicuous cyioskeleton continued to aggregate, forming the epithelioid cords; cell junction devices - dense plaques and plasma membrane anchorages - were observed. The newlyformed cords were surrounded by a basal lamina connected to a fibrillar network lying between the cords (figs. 19, 29). As previously emphasized by Stahl and Carlon (1973) and Bergeaud ef al. (1977), few, if any, PGC's were found in this area.

C. Loose stroma and axial mesenchyme. - From stage 23 onwards, a mesenchymal tissue of widely separated cells, surrounded by an extracellular matrix, was observed just dorso-lateral to the dense gonadal stroma, ventro-lateral to the mesonephros, and also in the dorsal axial mesentery, so that it was difficult to determine exactly the boundaries of the gonad itself. As indicated by Swartz and Domm (1972), the PGC population, composed of either single cells or groups of 2 or 3 PGC's greatly increased in this area (figs. 23, 24). Our study puts special emphasis on the relationships between the PGC's and the mesenchymal fibroblastic cells. It was found that the migrating PGC's, having left the blood vessels situated more dorsally, appeared as polarized cells ; this fact was indicated by the presence of a wide pseudopodia at the leading edge of the cell (fig. 23) and by the position of the Golgi apparatus and sometimes of a centriole at the trailing edge. Long and thin filopodia emerging from several neighbouring fibroblastic cells frequently surrounded the trailing edge of the PGC (fig. 24). The fibroblastic cells were polarized in the same direction as the PGC's. Dense focal plaques were constantly found between the PGC's and the mesenchymal cells (figs. 23, 24, 25).

FIG. $22(\times 45000)$. - Stage 27. Interfacing between the GE and dense stromal cords (DC). Note the basal proliferation of GE cells, rich in microfilaments (MF), pushing back the basal lamina (arrows).

FIG. 23 ( $\times 36000)$. - Stage 23. A PGC migrating through the loose gonadal stroma: Thin microfilaments (MF) are visible at the leading edge of the PGC pseudopodia. Dense plaques (arrow) are present between the PGC and a somatic mesenchymal cell (SMC).

FIG. $24(\times 8000)$. - Stage 23. A group of polarized PGC's migrating dorso-ventkally (DV) in the dorsal mesenfery. The PGC's are associated with several somatic mesenchymal cells (SMC).

FIG. 25 ( $\times 20000)$. - Detail of the inset in figure 24 showing a dense plaque between a PGC and a somatic cell (SMC). 
The former displayed only thin microfilaments clustered beneath the plasma membrane of the pseudopodia (fig. 23) and scarce microtubules, whereas the mesenchymal cells were very rich in both microtubules and microfilaments.

4) Stages 25 to 27 . - These stages are marked by increasing asymmetry between the left and the right gonads (figs. 9, 10,17), the germ and the somatic cells of the former proliferating faster (Van Limborgh, 1968 ; Stahl and Carlon, 1973 ; Fargeix ef al., 1976 ; Bergeaud et al., 1977). The right gonad was composed of a flat mono or bilayered GE whose epithelial cells were separated by narrow intercellular spaces ; the epithelial basal lamina was of the same type as described above (fig. 30); beneath the GE some epithelioid cords formed the dense stroma. In contrast to the left gonad, the loose stroma of the right gonad was poorly represented by one single layer of roughly polygonal mesenchymal cells with only short, rare filopodial expansions. In some cases, the loose stroma was even lacking.

In the left gonad, the proliferation process that had started in the GE at stage 21 continued so that the left GE appeared as a multilayered sheet of polarized epithelial cells and unorientated PGC's. Anchorage devices developed between the epithelial and the germ cells (fig. 21). The wide intercellular spaces previously described could no longer be seen, and the lateral membranes of the neighbouring cells straightened, coming into close apposition. It should be noted that the branching expansions, blebs and microvilli seen at earlier stages, and documented from stage 26 onwards by scanning electron microscopy (Didier et al., 1978), could still be observed from the apical membrane lining the coelomic cavity. The bulge of the GE basal face continued, forming an epithelioid area (including PGC's) connecting the GE and the dense stroma. Stahl and Carlon (1973), in their light microscope study of this process, indicated that the basal lamina was disrupted by this time. Using transmission electron microscopy, we found that the basal lamina was progressively disorganised concomitant with epithelial proliferation which started in the gonadal median axis, then spread towards the periphery of that organ (fig. 10): the lucent lamina interna was no longer visible and dense amounts of fibrillar extracellular material were found directly coating the epithelial cell membranes (fig. 20). This dense material was connected laterally to the material joining the basal lamina of the epithelioid cords to the dense stroma. No structural difference could be detected between the first set of cords, derived from condensed mesenchymal cells, and the newly-formed epithelioid area arising from GE basal proliferation.

\section{Discussion.}

\section{Morphogenetic events during gonadal development.}

Our study contributes additional information on the embryological origin of the primitive gonadal stroma which is still a matter of controversy in birds (see discussions in Stahl and Carlon, 1973, and in Merchant-Larios, 1978) as well as in mammals (Merchant-Larios, 1979 ; Upadhyay et al., 1979 ; Zamboni et al., 1979). Observations at very early stages reveal the unambiguous splanchnopleural origin of the forming gonad which first develops quite distinctly from the nephrotome situated more dorsally. As 
early as day 2 (stage 14-15), the gonadal anlage, appearing as a local differentiation of the splanchnopleural sheet, is obviously epithelio-mesenchymal in structure. It has been shown by electron microscopy that stromal organization starts as early as stage 15 with self-assemblies of mesenchymal cells, leading to the formation of the inner epithelioid cords previously described in more advanced embryos (Stahl and Carlon, 1973 ; Merchant-Laxios, 1978). We observed the ultrastructural details of cord morphogenesis : the fibroblastic aspect of the mesenchymal cells, the development of focal contacts (dense plaques) and anchorages between the aggregating cells and of deposits of fibrillar extracellular material, then the appearance of an organized basal lamina around the cords. It is not known whether the dense plaques result from collisions between migrating fibroblastic cells, as in other systems (Heaysman and Pegrum, 1973 ; Ebendal, 1977), or whether they mediate cell recognition in the self-assembly process.

Beginning at stage 18 discretely, and then increasing from stage 23 onwards, an intense proliferation of the GE basal area brings the GE and the enclosed PGC's in continuity with the first set of epithelioid cords ; proliferating epithelial cells, very rich in microfilaments and microtubules, spread underneath the GE through disruptions in the basal lamina, and aggregate to the primitive cords. As during the morphogenesis of other avian or mammalian organs (Wrenn, 1971 ; Slavkin et al., 1969 ; Bernfield and Wessels, 1970), the interfacing between the GE and the stromal mesenchyme might be of some importance during this process. The changes in the fine structure of the epithelial basal lamina have been described during gonadal development. Although similar at first to the basal laminae found in early chick embryos (Sanders, 1979), the basal lamina related to GE proliferation, when disorganized, leads to changes in the distribution of the extracellular material coating the cell membranes. Whether some of these structural changes are related or not to chemical modifications of the extracellular material still remains to be discovered.

Concomitant with this epithelial proliferation (which is thought essential in the morphogenesis of the medulla : Kopp and Bertrand, 1978), the more dorsal mesenchymal cells aggregate and generate a second series of epithelioid cords which do not display any structural difference with the early cords derived from the splanchnopleural sheet and progressively incorporated into the growing medulla (Merchant-Larios, 1978). This second set of cords may originate from the intermediate mesoderm ; indeed, from stage 18 onwards the developing uro-genital organs shift as a consequence of gut closure and probably of differential growth in the splanchnopleura and the somatopleura. This shift brings the loose gonadal mesenchyme in close continuity with both the mesonephric and the mesenteric mesenchymes, so that the contribution of the mesonephric cells to further gonadal development cannot be ruled out. However, this process would not involve the participation of the mesonephric epithelial tubes as in sheep or mouse embryos (Zamboni et al., 1979 ; Upadhyay ef al., 1979), but rather an incorporation of the mesenchymal cells originating from the intermediate mesoderm. Such a contribution is in good agreement with previous experimental data showing that the inhibition of mesonephric morphogenesis is followed by a noticeable reduction in the stroma and in the gonocyte population of the developing gonad (Didier and Fargeix, 1973). Finally, in avian embryos, we agree with Merchant-Larios's proposal (1978) that the gonadal stroma does not derive only from the mesonephric blastema, as 
Witschi (1951) claimed, but appears as the juxtaposition of early cords of splanchnopleural origin and of those developed later and possibly arising from the mesonephric or mesenteric mesenchyme of the intermediate mesoderm.

\section{Ultrastructural characteristics of the developing gonads.}

Concomitant with the morphogenetic events described above, the developing gonads are progressively colonized by PGC's carried to the genital area by the blood stream. In our study, special attention has been given to the morphological relationships between the somatic and the germ cells which both contribute to gonadal morphogenesis. Our observations agree with those previously made in the chick embryo which underline the polymorphic and amoeboid aspect of the migrating PGC's (Cuminge and Dubois, 1971 ; Fujimoto et al., 1976). In addition, we observed that the PGC's display a very low-level cytoskeletal organization since only a few microfilamentous bundles were observed beneath the plasma pseudopodial membranes. This feature, shared by avian and amphibian embryos (Heasman and Wylie, 1978), could account for the fact that PGC migration fails to be inhibited by cytochalasin B (Dubois and Cuminge, 1974).

The high PGC carbohydrate content, first noted by Meyer (1961) with the periodic acid-Schiff reaction (PAS), is another characteristic. PA-T-Ag-treated sections with an appropriate incubation time in thiocarbohydrazide indicated that the round, $50-\mathrm{nm}$ diameter granules, observed after conventional contrasting (Fujimoto et al., 1976), are $\beta$-glycogen particles clustered into $\alpha$-particles. However, it should be noted that the glycogen particles revealed by electron microscopy after the highly specific PA-T-Ag reaction are smaller and more finely granular than the PAS-positive granules observed by light microscopy (Nieuwkoop and Sutasurya, 1979). Further information on biosynthesis, storage and degradation of glycogen in gonocytes should be useful since it is not well known whether this material provides the energy required for migration (Clawson and Domm, 1963a,b) or whether it is a precursor of the cell surface glycoconjugates present in the migrating PGC's (Fargeix ef al., 1980).

FIGS. 26, 27, 28, 29. - Formation of primifive epithelioid stromal cords from the condensed splanchnopleural mesenchyme.

FIG. $26(\times 25000)$. - Stage 17. Early aggregating mesenchymal cells. Note the intricacy of cell membranes (arrow) and deposits of fibrillar material (asterisks) around the forming cord.

FIG. 27 ( $\times 30000)$. - Microfubules (MT) and microfilaments (MF) in a stromal mesenchyme cell.

FIG. $28(\times 30000)$. - A dense plaque between two apposed mesenchymal cells.

FIG. $29(\times 5000)$. $-A$ dense epithelioid cord at stage 26 . Note the fibrillar material (asterisks) around the cord.

FIG. 30 ( $\times 32000$ ). - Right gonad at stage 25 contrasted with left gonad (figs. 7, 8, 22) : the GE fails to thicken and proliferate; basal interspaces are still present ; the basal lamina (BL) is unmodified. 


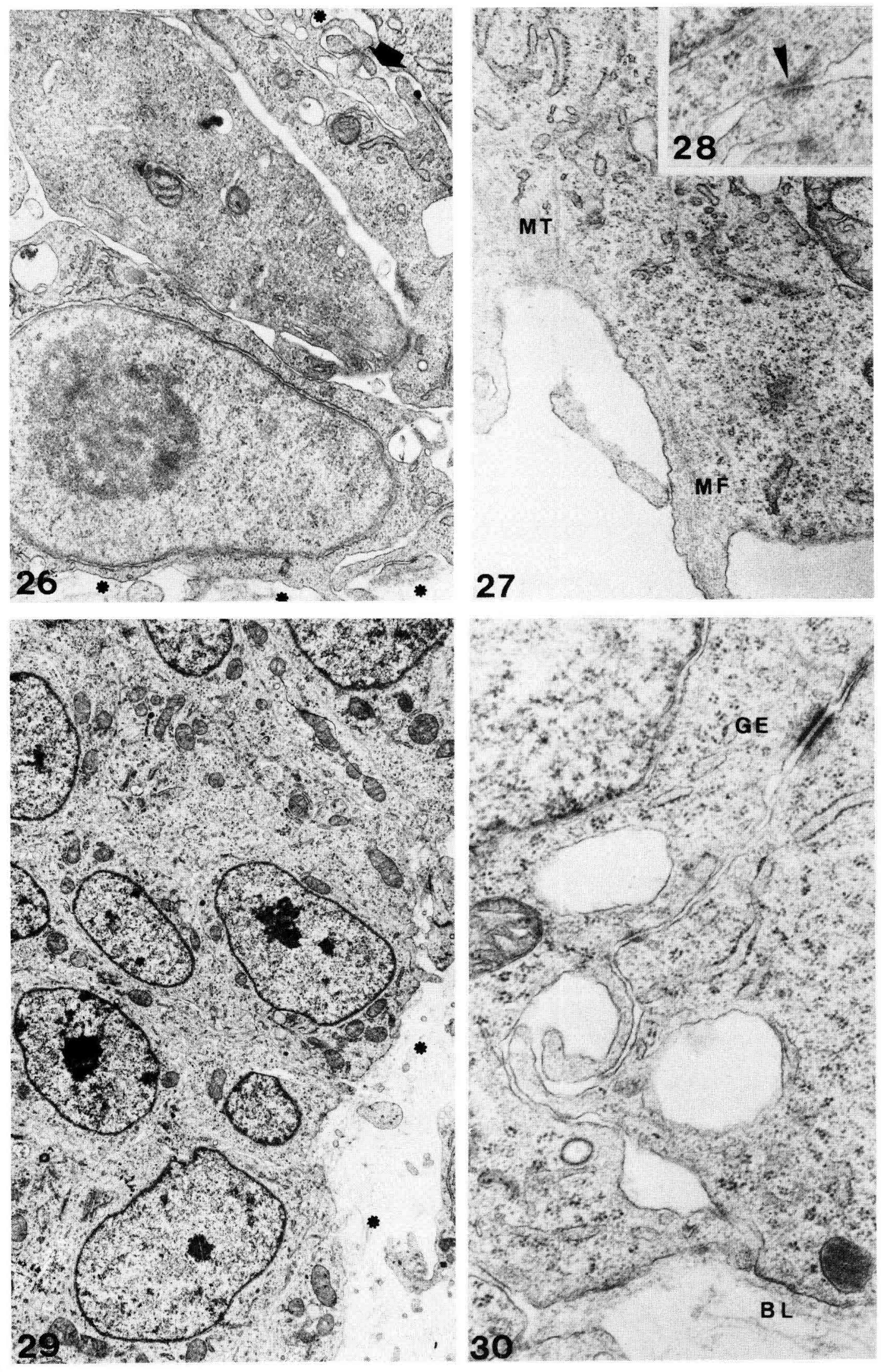


This selective glycogen labeling was convenient for identifying germ cells in the absence of any other clue such as chromatin structure, clustered mitochondria or liposomes. This method reveals the intricacy of the respective filopodial expansions emerging from both somatic and germ cells. At early stages, it was seen that the PGC's enclosed in the GE were surrounded by interspaces and did not develop any junctional device linking them to the somatic cells until stage 25 when $G E$ proliferation increased, connecting the GE with the primitive stroma. Another type of somato-germinal association was found in the gonadal and the perigonadal mesenchyme where polarized PGC's were frequently associated by dense plaques to fibroblast-like cells polarized in the same direction. However, it cannot be concluded from morphological studies whether these dense plaques are transient devices of attachment to the somatic cells, which could act as substrates for migrating PGC's, or adaptive systems linking the somatic and the germ cells in movement.

Furthermore, the cell pattern in the gonadal mesoderm may be well-suited to PGC invasion. It has been shown that wide intercellular spaces are present not only in the mesenchymes but also in the newly-organized epithelia ; between stages 15 and 25 , the GE displays the kind of loose organization which might be convenient for PGC settlement. In addition, GE penetration can be accomplished since the basal lamina underlying the GE is incomplete ; from stage 23 onwards, the structure of both the gonadal and the mesenteric mesenchymes also seems well-suited to PGC invasion. Although the molecular mechanism coordinating cell migration is still unknown, it has been repeatedly suggested that extracellular materials (ECM) act as suitable substrates for migration in several developmental systems (reviews in Toole, 1976 ; Ebendal, 1977 ; Löfberg and Ahlfors, 1978). The preliminary data obtained by our group (Didier et al., 1980) reveal structural and cytochemical similarities between the mesenteric and the gonadal ECM and those involved in the migration of neural crest cells, sclerotome cells and axons (Ebendal, 1977 ; Löfberg and Ahlfors, 1978). Whether directionality of movement is guided by preferential adhesivity on some of these substrates, remains to be demonstrated for avian migrating PGC's.

Reçu en décembre 1980. Accepté en janvier 1981.

Acknowledgements. - This work was financed by the CNRS (ERA No 408 ; LA No 138). We wish to thank S. Vernerey, N. Benay, Y. Marand and J. L. Molat for their excellent assistance.

Résumé. Les premiers stades du développement des gonades chez l'embryon de Poulet ont été étudiés en microscopie optique et électronique et par la détection cytochimique du glycogène dans les cellules germinales primordiales (CGPs). Les étapes morphogénétiques sont présentées entre le $2^{\mathrm{e}}$ et le $5^{\mathrm{e}}$ jour (stades 14 à 27 ) ainsi que les caractères ultrastructuraux des diverses populations cellulaires.

Cette étude précise l'origine encore controversée de la médulla gonadique des Oiseaux : elle montre que l'essentiel de la médullaire primitive résulte de l'association de l'épithélium germinatif qui prolifère et de cordons épithélioīdes (précocement formés à partir de mésenchyme splanchnopleural condensé) ; la médulla incorpore ultérieurement d'autres cordons profonds, probablement développés à partir du mésenchyme du mésoderme intermédiaire. Les processus de condensation mésenchymateuse sont décrits (aggrégation des cellules au moyen de plaques denses et d'ancrages membranaires; dépôts de 
matériel extracellulaire fibrillaire autour des cordons) ainsi que les modifications ultrastructurales de la membrane basale de l'épithélium germinatif, progressivement refoulée vers l'intérieur puis désorganisée.

L'éłude des relations morphologiques entre les CGPs et les cellules somatiques a été facilitée par le marquage du glycogène dans ces dernières; alors que les CGP installées dans l'épithélium germinal ne présentent pas de complexes jonctionnels avec les cellules épithéliales avant le stade 26 , celles qui migrent dans le mésentère dorsal et le mésenchyme gonadique profond sont associées aux cellules somatiques au moyen de plaques denses. Les caractères cytologiques des CGP en migration sont décrits : polymorphisme, présence de pseudopodes et de filopodes, pauvreté en microfilaments, contenu important en particules d' $\alpha$-glycogène. Par ailleurs l'organisation cellulaire dans les tissus mésodermiques semble bien adaptée à l'invasion par les CGPs, à cause d'un vaste compartiment extracellulaire distribué dans le mésenchyme ainsi que dans les jeunes épithéliums et grâce à la présence de discontinuités dans la membrane basale.

\section{References}

BERGEAUD Y., FARGEIX N., DIDIER E., 1977. Etablissement de l'index d'asymétrie de répar. tition des cellules germinales entre les deux crêtes génitales chez l'embryon de poulet de race Hubbard. Arch. Anat. micr. Morph. exp. 66, 279-290.

BERNFIELD M.R., WESSELS N. K., 1970. Intra and extracellular control of epithelial morphogenesis. Dev. Biol. Suppl. 4, 195-249.

CARLON N., MIRRE C., KOPP F., STAHL A., 1974. Aspect ultrastructural de l'épithélium germinatif de la gonade au stade indifférent chez l'embryon de poulet. Arch. Anat. micr. Morph. exp., 63, 349-362.

CLAWSON R. C., DOMM L. V., 1963a. The glycogen content of primordial germ cells in the white Leghorn chick embryo. Anat. Rec., 145, 218-219.

CLAWSON R. C., DOMM L. V., 1963b. Developmental changes in glycogen content of primordial germ cells in chick embryo. Proc. Soc. exp. Biol. Med., 112, 533-537.

CUMINGE D., DUBOIS R., 1971. Etude ultrastructurale ef autoradiographique de l'organogenèse sexuelle précoce chez l'embryon de poulet. Exp. Cell Res., 64, 243-258.

DIDIER E., FARGEIX N., 1973. Etude comparée de la colonisation des gonades par les cellules germinales au cours du développement normal et après réduction expérimentale du territoire gonadique. Arch. Anat. Histol. Embryol., 56, 33-50.

DIDIER E., FARGEIX N., 1976. Aspects quantitatifs du peuplement des gonades par les cellules germinales chez l'embryon de caille (Coturnix cofurnix japonica). J. Embryol. exp. Morph., 35, 637-648.

DIDIER E., FARGEIX N., DIDIER P., 1980. Extracellular polyanions in the splanchnopleural mesoderm of the chick embryo. Biol. cell., 38, $11 a$.

DIDIER E., FARGEIX N., JACOB H. J., DIDIER P., 1978. Ultrastructural study of the genifal ridges in 4-5 day chick embryos by means of scanning and transmission electron microscopy (SEM and TEM). 13 ed Int. Embr. Conf., Berlin, 107 (abstr.).

DUBOIS R., CUMINGE D., 1974. Chimiotactisme ef organisation biologique : étude de l'installation de la lignée germinale dans les ébauches gonadiques, chez l'embryon de poulet. Ann. Biol., 13, 241-258.

EBENDAL T., 1977. Extracellular matrix fibrils and cell contacts in the chick embryo. Cell Tiss. Res., $175,439-458$.

FARGEIX N., DIDIER E., BERGEAUD Y., 1976. Le contrôle quantitatif de la population germinale des gonades chez les oiseaux. Bull. Soc. Zool. Fr., 102, 7-14.

FARGEIX N., DIDIER E., GUILLOT P., DAMEZ M., 1980. Utilisation de diverses lectines fluorescentes dans l'éfude des cellules germinales en migration chez l'embryon d'Oiseau. C. R. Acad. Sci. Paris, sér. D., 290, 999-1002.

FARGEIX N., DIDIER E., LUTZ H., 1980. Les cellules germinales de l'embryon d'oiseau : localisationprécoce, migration et colonisation des ébauches gonadiques. Bull. Assoc. Anat., 64, 143-172.

FUIIMOTO T., UKESHIMA A, KIYOFUJI R., 1976. The origin, migration and morphology of the primordial germ cells in the chick embryo. Anat. Rec.., 185, 139-154. 
HAMBURGER V., HAMILTON H. L., 1951. A series of normal stages in the development of the chick embryo. J. Morph., 88, 49-92.

HEASMAN J., WYLIE C. C., 1978. Electron microscope studies on the structure of motile primordial germ cells of Xenopus laevis in vitro. J. Embryol. exp. Morph., 46, 119-133.

HEAYSMAN J. E. M., PEGRUM S. M., 1973. Early contacts between fibroblasts : an ultrastructural study. Exp. Cell Res., 78, 71-78.

KOPP F., BERTRAND M. F., 1978. Origine de la médullaire primitive dans la gonade de l'embryon de poulet. Arch. Biol., 89, 267-296.

LÖFBERG J., AHLFORS K., 1978. Extracellular matrix organization and early neural cresi cell migration in the axolotl embryo. Zoon., 6, 87-101.

MERCHANT-LARIOS H., 1978. Ovarian differentiation, 57-61. In JONES R. E., The vertebrate ovary. Plenum Publ. Co.

MERCHANT-LARIOS H., 1979. Origin of the somatic cells in the rat gonad : an autoradiographic approach. Ann. Biol. anim. Bioch. Biophys., 19, 1219-1229.

MEYER D. B., 1961. The intraembryonic migration of primordial germ cells in staged chick embryos. Anat. Rec., 139, 314-315.

MEYER D. B., 1964. The migration of primordial germ cells in the chick embryo. Dev. Biol., 10,154-190.

NIEUWKOOP P. D., SUTASURYA L. A., 1979. Primordial germ cells in the chordates. In ABERCROMBIE M., NEWTH D. R., TORREY J. G., Develop. Cell Biol. Ser., 7, Cambridge Univ. Press, Cambridge.

RAHIL K. S., NARBAITZ R., 1972. Evolution of the lining bodies in the embryonic chick gonad. J. Embryol. exp. Morph., 28, 133-140.

SANDERS E. J., 1979. Development of the basal lamina and extra-cellular materials in the early chick embryo. Cell Tiss. Res., 198, 527-538.

SIMONE-SANTORO I. de, 1969. Morphologie ultrastructurale de l'ovaire de l'embryon de poulet au cours de sa différenciation et de son organogenèse. J. Micr., 8, 739-752.

SLAVKIN H. C., BRINGAS P., CAMERON J., LeBARON R., BAVETTA L. A., 1969. Epithelial and mesenchymal cell interactions with extra-cellular matrix material in vitro. J. Embryol. exp. Morph., 22, 395-405.

STAHL A., CARLON N., 1973. Morphogenèse des cordons sexuels et signification de la zone médullaire de la gonade chez l'embryon de poulet. Acta anot., 85, 248-274.

SWARTZ W. J., DOMM L. V., 1972. A study on division of primordial germ cells in the early chick embryo. Am. J. Anat., 135, 51-70.

SWIFT C. H., 1915. Origin of the definitive sex-cells in the female chick and their relation to the primordial germ cells. Amer. J. Anat., 18, 441-470.

SWIFT C. H., 1916. Origin of the sex cords and the definitive spermatogonia in the male chick. Amer. J. Anat., 20, 375-410.

THIÉRY J. P., 1967. Mise en évidence des polysaccharides sur coupes fines en microscopie électronique. J. Micr., 6, 987-1018.

TOOLE B. P., 1976. Morphogenetic role of glycosaminoglycans (acid mucopolysaccharides) in brain and other tissues. In S. BARONDES, Neuronal recognition, Chapman and Hall, London.

UKESHIMA A., FUIIMOTO T., 1978. Scanning electron microscopy of primordial germ cells in early chick embryos. J. electr. Micr., 27, 19.

UPADHYAY S., LUCIANI J. M., ZAMBONI L., 1979. The role of the mesonephros in the development of indifferent gonads and ovaries of the mouse. Ann. Biol. anim. Bioch. Biophys., 19, 1179-1196.

Van LIMBORGH J., 1968. Le premier indice de la différenciation sexuelle des gonades chez l'embryon de poulet. Arch. Anat. micr. Morph. exp., 57, 79-90.

WITSCHI E., 1951. Embryogenesis of the adrenal and the reproductive glands. Recent Progr. Hormone Res., 6, 1-27.

WRENN J. T., 1971. An analysis of tubular gland morphogenesis in chick oviduct. Dev. Biol., 26, 400 . 415.

ZAMBONI L., BÉZARD J., MAULÉON P., 1979. The role of the mesonephros in the development of the sheep fetal ovary. Ann. Biol. anim. Bioch. Biophys., 19, 1153-1178. 